\title{
Active membrane transport and receptor proteins from bacteria
}

M. Saidijam, K.E. Bettaney, G. Szakonyi, G. Psakis, K. Shibayama, S. Suzuki, J.L. Clough, V.

Blessie, A. Abu-bakr, S. Baumberg, J. Meuller, C.K Hoyle, S.L Palmer, *P. Butaye,

*K.Walravens, S.G. Patching, J. O’Reilly, N.G. Rutherford, **R.M. Bill, ***D.I. Roper, M.K. Phillips-Jones and P.J.F. Henderson ****

Astbury Centre for Structural Molecular Biology, University of Leeds, Leeds LS2 9JT, UK

$* * * *$ Corresponding author:

Peter JF Henderson

Astbury Centre for Structural Molecular Biology,

School of Biochemistry and Microbiology,

University of Leeds,

Leeds LS2 9JT, UK

Phone: 44-113-343-3175;

Fax: 44-113-1407

Email: p.j.f.henderson@leeds.ac.uk

*Department of Bacteriology and Immunology

Veterinary and Agrochemical Research Centre

VAR-CODA-CERVA

Groeselenberg 99

B-1180 Ukkel

Belgium

\footnotetext{
**Aston Academy of Life Sciences

Aston University

Aston Triangle

Birmingham B4 7ET

UK
} 


\author{
***Department of Biological Sciences \\ University of Warwick \\ Gibbet Hill Road \\ Coventry CV47AL \\ UK
}

Key words: membrane transport proteins, two-component systems, pathogens, Helicobacter pylori

Abbreviations: dodecyl- $\beta$-D-maltoside, DDM; Nickel nitrilo-triacetate, NiNTA. 


\begin{abstract}
A general strategy for the expression in Escherichia coli of bacterial membrane transport and receptor genes is described. Expression is amplified so that the encoded proteins comprise 5-35\% of E. coli inner membrane protein. Depending upon their topology, proteins are produced with $\mathrm{RGSH}_{6}$ or a Strep-tag at the C-terminus. These enable purification in $\mathrm{mg}$ quantities for crystallisation and NMR studies. Examples of one nutrient uptake and one multidrug extrusion protein from Helicobacter pylori are described. This strategy is successful for membrane proteins from Helicobacter pylori, Escherichia coli, Enterococcus faecalis, Bacillus subtilis, Staphylococcus aureus, Microbacterium liquefaciens, Brucella abortus, Brucella melitensis, Campylobacter jejuni, Neisseria meningitides, Streptomyces coelicolor and Rhodobacter sphaeroides
\end{abstract}




\section{Introduction}

The lipid cell membrane of bacteria is inherently impermeable to nutrients required for metabolism. Uptake of nutrients (and secretion of wastes) therefore depends on the presence of transport proteins, activities of which are typically coupled to metabolic energy to drive transport against the prevailing electrochemical gradient of solute. Examples are ATP-dependent primary active transport, sugar- $\mathrm{H}^{+}$or antibiotic $/ \mathrm{H}^{+}$secondary active transport and phosphotransferase [1] (Figure 1). In addition the bacterial membrane contains proteins that sense environmental conditions and, through the 'two-component' sensor/response system (TCS), facilitate an appropriate response of the cells [2] (Figure 1). In most cases the low abundance of these membrane proteins and their hydrophobic nature make them difficult to isolate in amounts required for elucidation of their 3D structure. Determination of structure is a major bottleneck in understanding the molecular mechanisms of membrane transport and sensor proteins, which comprise $5-15 \%$ of genomic potential in all organisms.

In this article a strategy is described that enables the amplified expression and purification of bacterial membrane transport and receptor proteins in amounts required for structural studies; the strategy is successful for many such proteins (Table 1). Many of these are prokaryote proteins homologous to those found in numerous organisms from cyanobacteria, eubacteria, protozoan parasites, fungi, plants and mammals [3]; the convenience of structure-activity studies in bacteria then illuminate the molecular mechanism of transporters in numerous organisms including man. Other transport systems and TCS's are unique to bacteria and critical for growth of pathogenic organisms during infection; the availability of the purified active protein may then be useful for discovery of novel antibacterials.

Only two examples of amplified expression are illustrated here, an $\alpha$-ketoglutarate transport protein (KgtP) and a putative multidrug resistance protein (Mdr), both originating from Helicobacter pylori. Tomb et al. [4] determined the complete genome sequence of the H. pylori strain 26695, later compared with that of the pathogenic strain J99 [5]. One of the genes found was JHP0334. This was thought to encode an $\alpha$-ketoglutarate membrane transport protein, because its predicted amino acid sequence aligned with 40-44\% identity to the known 'KgtP' protein from Escherichia coli [3, 6]. Homologues of KgtP also occur in Campylobacter jejuni, Salmonella typhimurium, Pseudomonas putida, Salmonella typhi and Brucella suis. The JHP0334 gene product is predicted to comprise 437 amino acids. Similarly, the JHP1092 gene 
product is thought to encode an efflux protein for drugs and/or antibiotics of 386 amino acids. Both proteins belong to the widespread Major Facilitator Superfamily of transport proteins [7] and their hydropathy profiles suggest they are integral membrane proteins arranged in 12 transmembrane $\alpha$-helices. Their transport is likely to be energised by the transmembrane electrochemical potential of $\mathrm{H}^{+}$, but this is not proven; where the nature of the cation linkage is thought to be established it is indicated in Table 1.

\section{Materials and methods}

The materials and methods used in this work are described in [8-12]. Genomic DNA from H. pylori strains J99 and 26695 was kindly provided by D. E. Berg (St Louis), from Campylobacter jejuni and Neisseria meningitidis by M.C.J. Maiden (Oxford), from Brucella abortus by R.C. Essenberg (Ohio) and from Brucella melitensis by K Walravens (Brussels). Bacillus subtilis was kindly provided by A. Moir (Sheffield). n-Dodecyl-beta-D-maltoside (DDM) was from Melford Labs, Ipswich, Suffolk. Nickel nitrilo-triacetic acid (NiNTA) and an antibody against the $\mathrm{RGSH}_{6}$ epitope were from QIAgen, Ltd., Dorking, Surrey.

E. coli strains XL1-Blue Stratagene ${ }^{\mathrm{TM}}$ (recA1, endAI, gyrA96, thi-I, hsdR17, supE44, relA1,

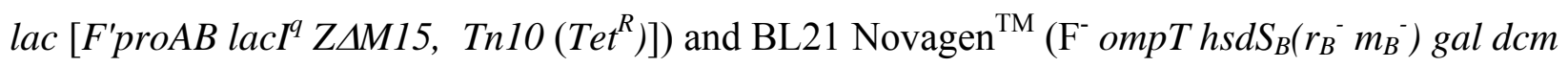
(DE3)) were used as hosts for transformation work. E. coli BL21(DE3) was also used for smalland large-scale isolation of plasmids, and for over-expression and purification of transport proteins.

Maintenance and growth of these E. coli strains was achieved by culturing the bacteria in Luria Broth (LB) [9] liquid medium, or in minimal salts medium [9] containing 20mM glycerol, or on plates containing $1.5 \%$ agar. Carbenicillin (at least $100 \mu \mathrm{g} / \mathrm{ml}$ ) was used throughout all stages of growth to maintain plasmid integrity.

For small-scale investigation of protein expression, $50 \mathrm{ml}$ cultures in $250 \mathrm{ml}$ flasks were used. Total membranes were prepared from sphaeroplasts by the water lysis method [9]. Inner membrane vesicles were prepared from $500 \mathrm{ml}$ cultures in 21 baffled conical flasks or from 251 fermentor cultures. After harvesting the cells were disrupted by explosive decompression using a 
French pressure cell. The inner and outer cell membranes were separated by sucrose density centrifugation, followed by washing in buffer to remove the sucrose and EDTA [9].

For both small-scale and inner membrane production of E.coli strains, growth was allowed to continue until the cell density reached an $\mathrm{A}_{680}$ of approximately 0.6 when the expression of the cloned gene was induced by the addition of isopropyl- $\tilde{\beta}$ D-thiogalactopyranoside (IPTG) to a final concentration of $0.5 \mathrm{mM}$. Growth was continued for $3-4 \mathrm{hrs}$ following the induction of the tac promoter, thus producing optimal yields of protein.

\section{Results}

\section{Introduction of the gene encoding a putative symport or antiport protein into the plasmid pTTQ18}

The genes putatively encoding the $\alpha$-ketoglutarate or the $\mathrm{Mdr}$ transport proteins were amplified from the $H$. pylori genomic DNA, using appropriate mutagenic oligonucleotides. These were designed to introduce an EcoRI site at the 5' end and a PstI site at the 3 ' end to promote subsequent ligation with the $4.56 \mathrm{~kb}$ pTTQ18/ $\mathrm{RGSH}_{6}$ fragment. The PCR product was isolated from an agarose gel and then digested with EcoRI and PstI.

In order to clone each of the genes into the pTTQ18 plasmid vector [13], the plasmid pNorAH6 (pTTQ18 containing the gene norAH 6 [14], Figure 2) was isolated from E. coli strain BLR and digested with the restriction endonucleases EcoRI and PstI to yield two DNA fragments of $4.56 \mathrm{~kb}$ and $1.2 \mathrm{~kb}$. The larger fragment (pTTQ18 with the $\mathrm{RGSH}_{6}$ coding DNA sequence) was isolated from an agarose gel.

Ligation reactions were performed using the EcoRI-PstI digested gene and pTTQ18-RGSH 6 fragments at various vector:insert molar ratios. After the ligated product was transformed into $E$. coli XL1-blue, recombinant clones were selected on LB plates containing carbenicillin. Plasmid DNA was prepared from carbenicillin-resistant colonies and subjected to restriction analysis with HindIII, NcoI (not shown) uniquely-cutting restriction enzymes and automated DNA sequencing of the $5^{\prime}$ end. to confirm the correct size of the plasmid and the presence of each gene [11]. The 
size and DNA sequence of the inserts in the new plasmids (Figure 2) were confirmed. The plasmid was then transformed into E. coli strain BL21(DE3) for expression studies.

This procedure can be applied to any gene that does not include EcoRI or PstI restriction sites. If these sites are present in the coding region then EcoRI and PstI can still be introduced as flanking sites and partial digestion used to obtain a fragment uncut at the internal site(s), or a two-step procedure adopted as in [12]. Alternatively, other flanking restriction sites can be chosen compatible with the multi-cloning site in pTTQ18 [9, 13], for example NdeI at the 5' and HindIII at the 3 'end of the gene. If the C-terminus is predicted to lie in the periplasm then a Strep-tag may well be successful if the $\mathrm{RGSH}_{6}$ tag is not.

\section{Detection of expressed histidine-tagged transport protein in $E$. coli membrane preparations}

E. coli BL21(DE3) cells harbouring each plasmid were cultured in LB broth plus 20mm glycerol and expression trials performed with concentrations of IPTG 0.0-1.0mM [11]. 0.5mM IPTG is sufficient for maximal expression of the putative $\mathrm{KgtP}(\mathrm{His})_{6}$ and JHP1092 Mdr proteins.

After preparing membrane samples [9, 10, 11], SDS-PAGE analysis and staining with Coomassie brilliant blue, an IPTG-inducible protein is observed migrating at approximately 35 $\mathrm{kDa}$ for $\mathrm{KgtP}(\mathrm{His})_{6}$ and at approximately $31 \mathrm{kDa}$ for JHP1092(His) 6 (Figures 3A and 3B). It is typical for membrane transport proteins to migrate at $65-75 \%$ of their true molecular weight, possibly as a result of their hydrophobicity, high binding of SDS or the retention of secondary structure retarding passage through the gel mixture [9]. This is also the case for membrane sensor proteins of TCS, though the extent of anomalous migration behaviour is not as great, possibly due to fewer TM regions in these proteins compared with membrane transport proteins. The predicted molecular weight of $\mathrm{KgtP}(\mathrm{His})_{6}$ is $50,245.3 \mathrm{Da}$, so the migrating protein would be expected at $32-37 \mathrm{kDa}$, and for JHP1092(His) 6 it is $44,994 \mathrm{kDa}$ so the expected apparent mass is 29-34 kDa. Scanning densitometry analysis showed that the induced proteins were expressed at $20 \%$ of total membrane proteins, indicating that over-expression has occurred, whereas the protein at the same position in the uninduced sample is expressed at $3 \%$ of inner membrane protein. Their identities in the membranes were further confirmed by Western blotting [10, 11].

\section{Solubilisation and purification of histidine-tagged transport proteins}


Initial purification of $\mathrm{KgtP}(\mathrm{His})_{6}$ or JHP1092(His) 6 using Immobilised Metal Affinity Chromatography (IMAC) to exploit the C-terminal His-tag (Methods) show proteins migrating at 35 or $31 \mathrm{kDa}$, respectively in the eluted fractions following Coomassie blue or silver-staining (Figure 3A \& 3B), similar to the IPTG-inducible proteins migrating in the inner membrane fractions (Figure 3A \& 3B).

In order to reinforce identification and integrity of the isolated proteins the gels were subjected to Western blot analysis using an antibody to the C-terminal RGS(His) 6 tag. Both purified proteins reacted with the antibody (Figure 3A \& 3B). N-Terminal sequencing further confirmed their identification and, importantly, the integrity of the amino acid sequences of the purified proteins (MNSH MNPQIQ for $\mathrm{KgtP}(\mathrm{His})_{6}$ and $\mathrm{MNSH}$ MLRKNILAY for JHP1092(His) 6 , the first four amino acids are from the LacZ $\alpha$ peptide). Some minor contaminants (hardly visible on silver staining) in $\mathrm{KgtP}(\mathrm{His})_{6}$ preparations of lower $\mathrm{Mr}$ were positive with the antibody (Figure 3), suggesting that some breakdown of the purified protein may have occurred, while bands of higher Mr may be oligomers of each protein (Figure 3A \& 3B).

Thus, the uncertainty of the identity of the protein resulting from the anomalous migration on SDS-PAGE gels is overcome by the combined detection of the predicted N-terminal sequence and Western blot analysis for the C-terminal RGS(His) 6 tag, confirming that the proteins migrating at $31-35 \mathrm{kDa}$ are the ones desired and that they have not been degraded during isolation. These are generic tests of integrity applicable to any -RGS(His) ${ }_{6}$-tagged proteins.

The conditions for solubilisation and purification, i.e. DDM concentration for solubilisation and imidazole concentration for washes and elution, vary depending on the characteristics of each of the transport proteins. However, the generic conditions described here for one symporter and one antiporter have proved feasible and provided an initial index of yield and purity.

\section{Retention of structure and activity is confirmed by circular dichroism spectroscopy and activity assays of reconstituted protein.}

CD spectroscopy is a useful technique for the detection of secondary structure within proteins, although the quantification of the proportions of different structural elements is severely limited for membrane proteins $[15,16]$. The CD spectra obtained for the purified 


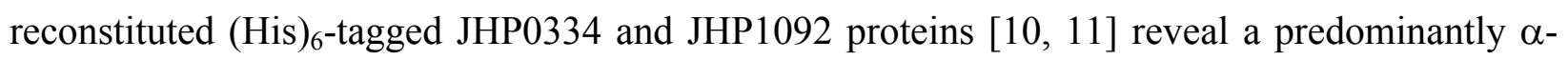
helix content, confirming retention of the secondary structure during purification of the protein. Furthermore, the purified reconstituted $\mathrm{KgtP}(\mathrm{His})_{6}$ protein catalysed $\alpha$-ketoglutarate counterflow into liposomes $[10,11]$.

In the case of TCS proteins activity of the protein expressed in membranes and also after purification can be established by direct assays of phosphorylation of the protein [12].

\section{Wider application of the strategy for amplified expression and purification of membrane proteins}

The same strategy, with minor modifications in growth and purification conditions, has been used for overexpression of other membrane transport and TCS proteins from H. pylori [e.g. 17], E. coli [e.g. 12, 18] and other bacteria, both Gram-negative and Gram-positive (Table 1). Out of 40 attempts, 34 have so far been successful for amplification of expression, i.e. the induced cloned protein comprised at least $15 \%$ of the inner membrane preparations of the E. coli host strain, and in every case (so far 16) where the (His) 6 tag was added at the C-terminus the protein has been purified successfully by NiNTA chromatography. In some cases where a parallel construct with the (His) ${ }_{6}$-tag at the N-terminus, instead of the C-terminus, was made, the level of expression was substantially reduced.

For each protein growth conditions should be optimised in 1-25 litre cultures of E. coli host strains, testing both minimal and complex media at temperatures between $25-37^{\circ} \mathrm{C}$ to maximise expression [9]. The concentration of IPTG required is tested between 0.1-1.0mM, and the period of growth before induction varied to obtain as high a cell density as possible commensurate with optimal protein expression (growth is often diminished, or abolished, after induction). Similarly, the period of exposure to IPTG (2-24 hours) is investigated in order to promote maximum expression. In many cases a 251 fermentor can conveniently be used without compromising expression, but for some proteins the level of expression is always higher in batch cultures of $500-800 \mathrm{ml}$ in 21 baffled flasks. Further examination of the parameters regulating growth and protein production in these conditions may enhance our understanding of expression and enable us to reproduce the complex growth behaviour in flasks in the more controlled environment of a fermentor. 


\section{Conclusions}

The prime purpose of this review is to illustrate a generic procedure for obtaining sufficient quantities of correctly folded transport and receptor protein(s) from a variety of microorganisms, including pathogens, for structural studies. This has been achieved for 12 organisms, both Gram positive and Gram negative, and for 34 proteins (Table 1). It is possible to proceed from identification of a gene encoding a membrane protein in a bacterial genome to the production of mg of purified protein in a few weeks, and the application of higher throughput methods for cloning and purification will hopefully reduce the time required. The yield and purity of protein may well be increased by further optimisation of conditions, especially for detergent extraction of protein from the membrane. The yields are easily enough for trials to form 2D ordered arrays for electron crystallography $[19,20]$, and sufficient to start $3 \mathrm{~d}$ crystallisation trials for Xray crystallography (Shibayama, Byrne, Iwata, Suzuki, Rutherford, O'Reilly and Henderson, unpublished) and for NMR studies [21,22].

In addition, the purified protein can be examined by a variety of biophysical techniques mass spectrometry for precise $\mathrm{Mr}$ and sequence determination [23, 24], FTIR, fluorimetry, calorimetry and EPR that elucidate the structure-activity relationship, especially when performed in conjunction with directed mutagenesis and genetic recombination.

The activity and bioenergetics of each cloned transport protein can be confirmed and/or investigated in IPTG-induced E. coli hosts, by measuring transport of radioisotope-labelled substrates [e.g. 10,11] or phosphorylation kinetics of TCS proteins [e.g. 12]. If there is no significant transport activity in an uninduced strain, but substantial activity in the IPTG-induced one, then any E. coli wild-type host and vesicles prepared therefrom can be used to investigate cation dependence, substrate specificity, susceptibility to inhibitors, etc. Nevertheless, it is 
preferable to use an E. coli host itself attenuated in the relevant transport system. Expression of genes encoded in the pTTQ18 vector is independent of the E. coli host in our experience so far, and movement between host strains by transformation is easily accomplished. By this means we have established, for example, that the $\mathrm{PutP}(\mathrm{His})_{6}$ protein from $H$. pylori catalyses proline- $\mathrm{Na}^{+}$ symport (11).

In recent landmark papers the 3D structures of the lactose and $\alpha$-glycerophosphate transport proteins (Fig. 1) of E. coli have been determined by X-ray crystallography [24, 25]. Future such elucidation of the structures of transport and other membrane proteins from the additional organisms described here may uncover means of preventing or treating bacterial infections.

\section{Acknowledgements}

This work was funded by BBSRC, EU, Ajinomoto Co., SmithKline Beecham (SB, now GlaxoSmithKline, GSK) and SWEGENE and by equipment grants from the Wellcome Trust and BBSRC. MS is grateful to the Iranian Government for financial support. BBSRC provided $\mathrm{PhD}$ studentships for JC, GP and SM, and MRC provided studentships for CKH and SLP. We thank Dr JG Keen for N-terminal amino acid sequencing of the purified proteins. We also acknowledge the constructive interest of Dr M Gwynne (GSK), Dr F Paul (GSK), Dr G Badman

(GSK) and Dr Watanabe (Ajinomoto Co.). PJFH is grateful for a Leverhulme Research Fellowship and KS for a JSPS/RS Travel Fellowship. 


\section{References}

1. Henderson, P.J.F. (1997) in: Transporters Factsbook (Griffith, J.K and Sansom, C.E., eds.). pp. 3-29, Academic Press, London

2. Hoch, J.A. and Silhavy, T.J. (1995) in: Two-component signal transduction (Hoch, J.A. and Silhavy, T.J., eds.) ASM Press, Washington.

3. Griffith, J.K. and Sansom, C.E. (1998) in: Transporter Factsbook (Griffith, J.K and Sansom, C.E., eds.). pp 335-363, Academic Press, London.

4. Tomb J.F. et al. (1997) Nature 388, 539-547.

5. Alm R.A. et al.. Nature. 1999; 397, 176-180.

6. Seol, W. and Shatkin, A.J. (1991) Proc. Natl. Acad. Sci. USA 88, 3802-06.

7. Pao S.S., Paulsen, I.T. and Saier M.H. (1998) Microbiol. Biol. Rev. 62, 1-32.

8. Clough, J.L. (2001) PhD Thesis, University of Leeds, UK

9. Ward, A., Sanderson, N.M., O'Reilly, J., Rutherford, N.G., Poolman, B. and Henderson, P.J.F. (2000) in: Membrane Transport - a Practical Approach (Baldwin, S.A., ed.) pp141166, Blackwell's Press :Oxford UK.

10. Saidijam, M., Psakis, G., Clough, J.L. Johan Meuller, J, Suzuki, S., Hoyle, C.J., Palmer, S.L., Morrison, S.M., Pos, M.K., Essenberg, R.C., Maiden, M.C.J., Abu-bakr, A., Baumberg, S.G., Stark, M.J., Ward, A., O’Reilly, J., Rutherford, N.G., Phillips-Jones, M.K. and Henderson, P.J.F. (2003) Collection and characterisation of bacterial membrane proteins. FEBS Lett. 555, 170-175.

11. Saidijam, M. (2004) PhD Thesis, University of Leeds, UK.

12. Potter, C.A., Ward, A, Laguri. C., Williamson, M.P., Henderson, P.J.F. and PhillipsJones, M.K. (2002) J. Mol. Biol. 320, 201-213

13. Stark M.J. (1987) Gene 51, 255-267.

14. Hoyle C.J. (2000) PhD Thesis, University of Leeds.

15. Wallace, B.A. and Teeters, CL. (1987) Biochem. 26, 65-70.

16. Wallace, B.A, Lees, J., Orry, A.J.W., Lobley, A. and Janes, RW. (2003) Protein Sci. 12, 875-884.

17. Morrison, S., Ward, A., Hoyle, C.J. and Henderson, P.J.F. (2003) Intern J. Antimicrob. Ag. 22/3, 242-249. 
18. Liang, W-j, Xie, H., Wilson, K., Rutherford, N.G., Henderson, P.J.F. and Jefferson, R. (2005) J. Bacteriol. 187, 2377-2385.

19. Yin, C-C., Aldema-Ramos, M.L., Borges-Walmsley, M.I., Taylor, R.W., Walmsley, A.R., Levy, S.B. and Bullough, P.A. (2000) Mol. Microbiol. 38, 482-492.

20. Hirai, T., Heymann, J.A.W., Shi, D., Sarker, R., Maloney, P.C. and Subramanian, S. (2002) Nature Struct. Biol. 9, 597-600.

21. Patching, S.G., Herbert, R.B., O’Reilly, J., Brough, A.R. and Henderson, P.J.F. (2004) J. Am. Chem. Soc. 126, 86-87.

22. Patching, S.G., Brough, A.R., Herbert, R.B., Rajakarier, J.A., Henderson, P.J.F. and Middleton, D.A., (2004) J. Am. Chem. Soc. 126, 3072-3080.

23. Venter, H., Ashcroft, A.E., Keen, J.N., Henderson, P.J.F. and Herbert, R.B. (2002) Biochem. J. 363, 243-252

24. Le Coutre, J., Whitelegge, J.P., Gross, A., Turk, E., Wright, E.M., Kaback, H.R. and Faull, K.F. (2000) Biochem. 39, 4237-4242.

25. Abramson, J., Smirnova, I., Kasho, V., Verner, G., Kaback, H.R. and Iwata, S. (2003) Science 301, 610-615.

26. Huang, Y., Lemieux, M.J., Song, J., Auer, M. and Wang, Da-N. (2003) Science 301, 616620. 


\section{Figure legends}

Figure 1. Scheme for transport mechanisms and sensor kinases in bacteria. The oval represents the cytoplasmic membrane of a bacterium containing the enzymes of ATP synthesis and respiration on the left and in a clockwise direction: two symporters; two antiporters; a phosphotransferase; two ABC transporters for efflux and influx; and a TCS sensor kinase.

Figure 2. Cloning strategy for membrane proteins using plasmid pTTQ18. Details are given in refs [8-14].

Figure 3. (A) Purification (and identification) of the H. pylori $\mathrm{KgtP}(\mathrm{His})_{6}$ ketoglutarate transport protein. Membrane preparations were made from IPTG-induced E. coli BL21(DE3) (pTTQ18kgtP). Samples of the original preparation ('Membrane'), the proteins solubilised in $1.5 \%$ DDM ('Soluble') and insoluble ('Pellet') material were examined by SDS-PAGE (Coomassie-stained). A sample of the material that failed to adhere to $\mathrm{Ni}^{2+} \mathrm{NTA}$-agarose ('Flowthrough') and the $\mathrm{Ni}^{2+}$ NTA-bound protein subsequently eluted by $200 \mathrm{mM}$ imidazole ('Protein') were processed in the same gel. The eluted protein, $0.1 \mu \mathrm{g}$ and $0.5 \mu \mathrm{g}$, was also tested for reaction with anti-RGSH${ }_{6}$ antibody by 'Western blotting' .

(B) Purification (and identification) of the H. pylori JHP1092(His) 6 putative multidrug resistance protein. Samples from membranes of IPTG-induced E. coli BL21(DE3) (pTTQ18jhp1092) were prepared and are labeled as in A. The purified protein, $1 \mu \mathrm{g}$ and $2 \mu \mathrm{g}$ was also tested for reaction with an anti $\mathrm{RGSH}_{6}$ antibody by 'Western blotting' .

Table 1.

Examples of 34 overexpressed proteins and their 12 organisms of origin

$\begin{array}{lll}\text { Protein } & \text { Organism } & \text { Major substrate } \\ \text { KgtP (JHP0334) } & \text { Helicobacter pylori } & \text { Ketoglutarate } \\ \text { "ProP" } & \text { Helicobacter pylori } & ? \\ \text { GluP } & \text { Helicobacter pylori } & \text { Glucose } \\ \text { NupC } & \text { Helicobacter pylori } & ? \\ \text { PutP } & \text { Helicobacter pylori } & \text { Proline-Na }{ }^{+} \\ \text {NixA } & \text { Helicobacter pylori } & \text { Nickel }\end{array}$




\begin{tabular}{|c|c|c|}
\hline Hp1092 & Helicobacter pylori & Multidrugs \\
\hline Hp1181 & Helicobacter pylori & Multidrugs \\
\hline AraE & Escherichia coli & Arabinose- $\mathrm{H}^{+}$ \\
\hline XylE & Escherichia coli & Xylose- $\mathrm{H}^{+}$ \\
\hline GalP & Escherichia coli & Galactose- $\mathrm{H}^{+}$ \\
\hline ProP & Escherichia coli & Proline- $\mathrm{H}^{+}$ \\
\hline PutP & Escherichia coli & Proline- $\mathrm{Na}^{+}$ \\
\hline Bcr & Escherichia coli & Bicyclomycin \\
\hline FucP & Escherichia coli & Fucose- $\mathrm{H}^{+}$ \\
\hline GusB & Escherichia coli & Glucuronide- $\mathrm{H}^{+}$ \\
\hline “ProP” (Cj0250c) & Campylobacter jejuni & $?$ \\
\hline FucP (Cj0486) & Campylobacter jejuni & Fucose \\
\hline Nma2100 & Neisseria meningitidis & Sugar? \\
\hline GluP (Nma0714) & Neisseria meningitidis & Glucose \\
\hline “'Bcr” (Nma2040) & Neisseria meningitidis & Multidrugs? \\
\hline GluP & Brucella abortus & Glucose \\
\hline KgtP & Brucella melitensis & Ketoglutarate \\
\hline LmrB & Brucella melitensis & Lincomycin \\
\hline NorA & Staphylococcus aureus & Multidrugs \\
\hline Mj 1560 & Methanococcus janaschii & Multidrugs? \\
\hline Mhp1 & Microbacterium liquefaciens & Hydantoins \\
\hline AraE & Bacillus subtilis & Arabinose \\
\hline $\mathrm{Bmr}$ & Bacillus subtilis & Multidrugs \\
\hline Blt & Bacillus subtilis & Multidrugs \\
\hline VicK & Enterococcus faecalis & Signal? \\
\hline $\operatorname{VanS}_{\mathrm{A}}$ & Enterococcus faecalis & Signal? \\
\hline PrrB & Rhodobacter sphaeroides & Redox potential \\
\hline $\mathrm{SpdB}$ & Streptomyces coelicolor & DNA? \\
\hline
\end{tabular}


Published in Biochemical Society Transactions Volume 33, part 4

http://www.biochemsoctrans.org 


\section{Secondary active transport}

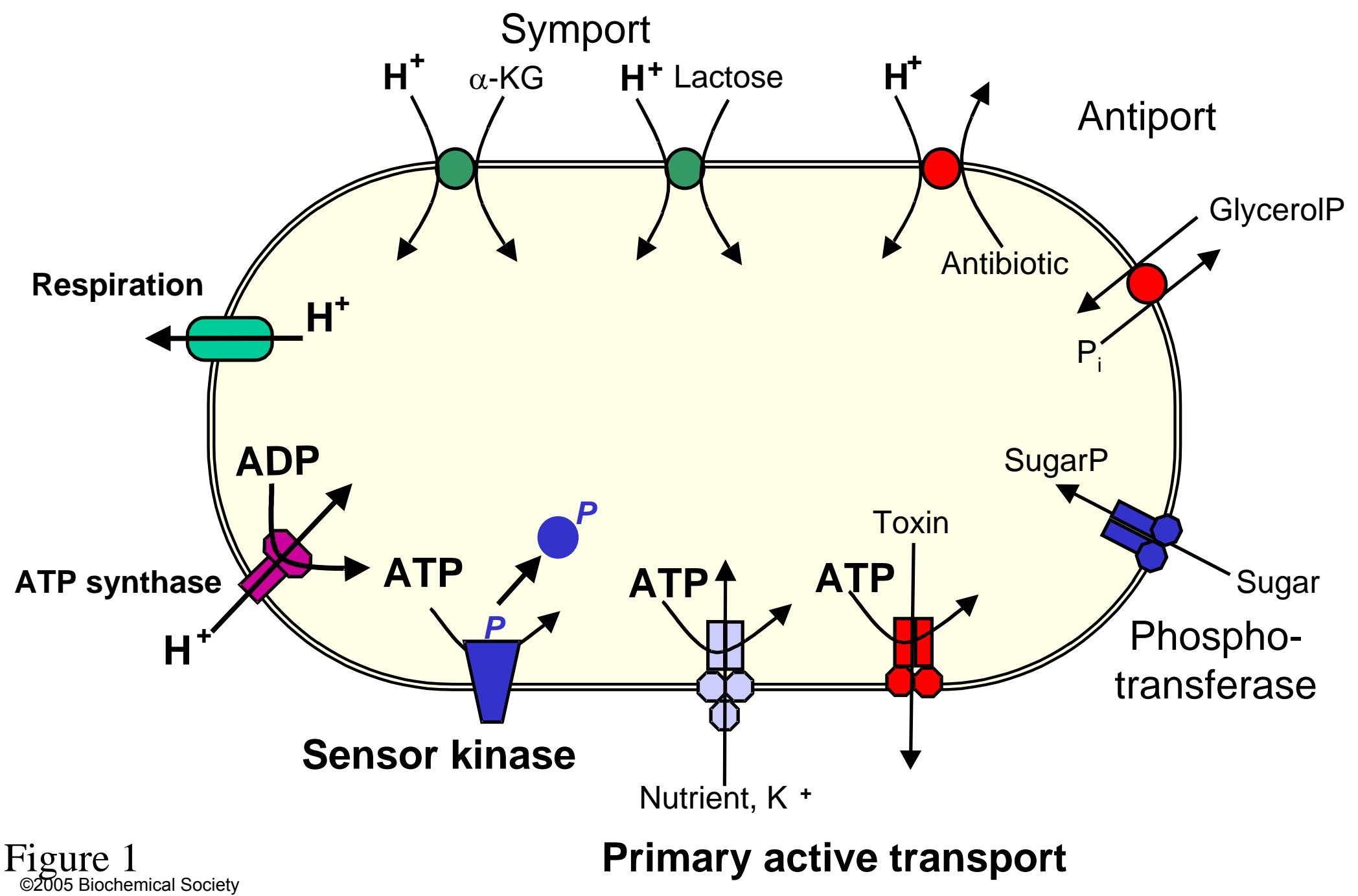


Published in Biochemical Society Transactions Volume 33, part 4 http://www.biochemsoctrans.org

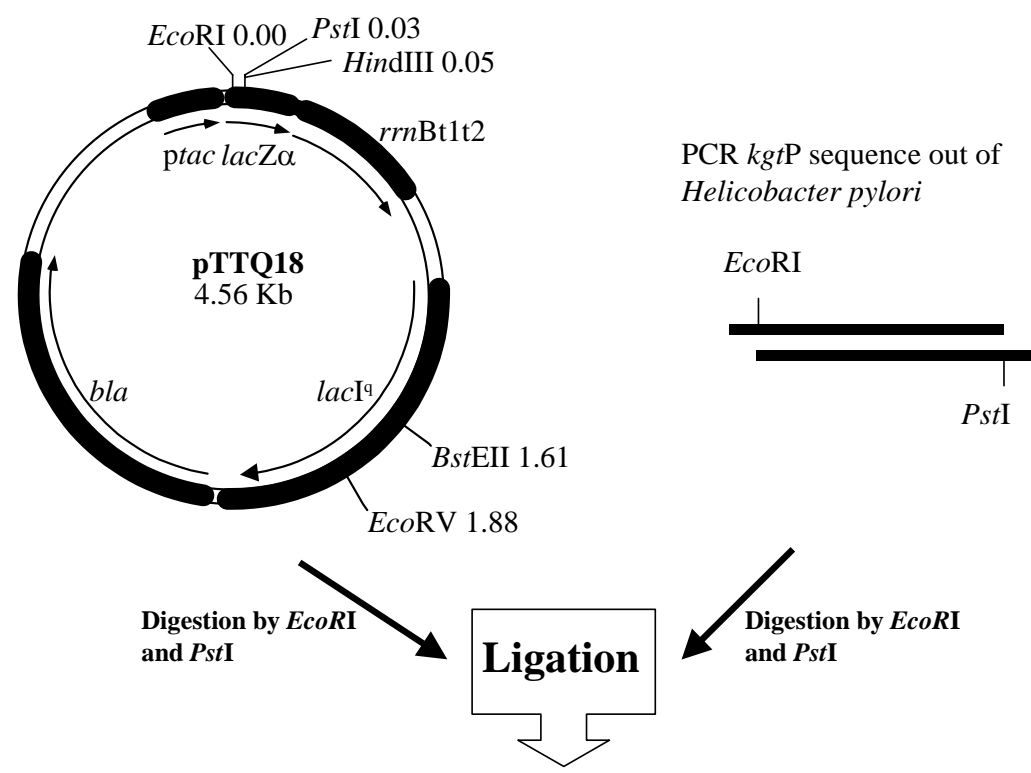

\section{Figure 2}

๑2005 Biochemical Society

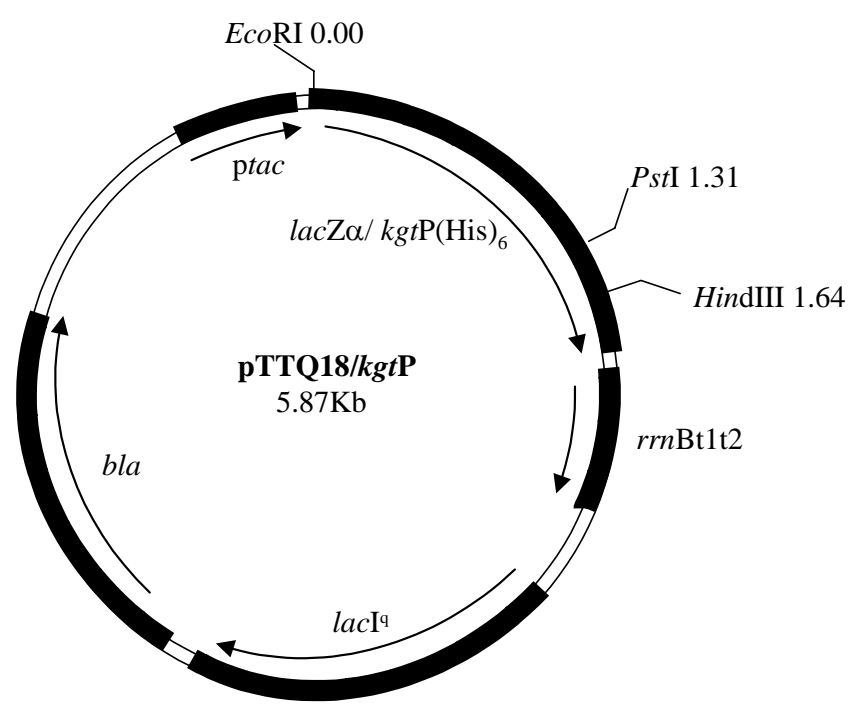


Published in Biochemical Society Transactions Volume 33, part 4

http://www.biochemsoctrans.org

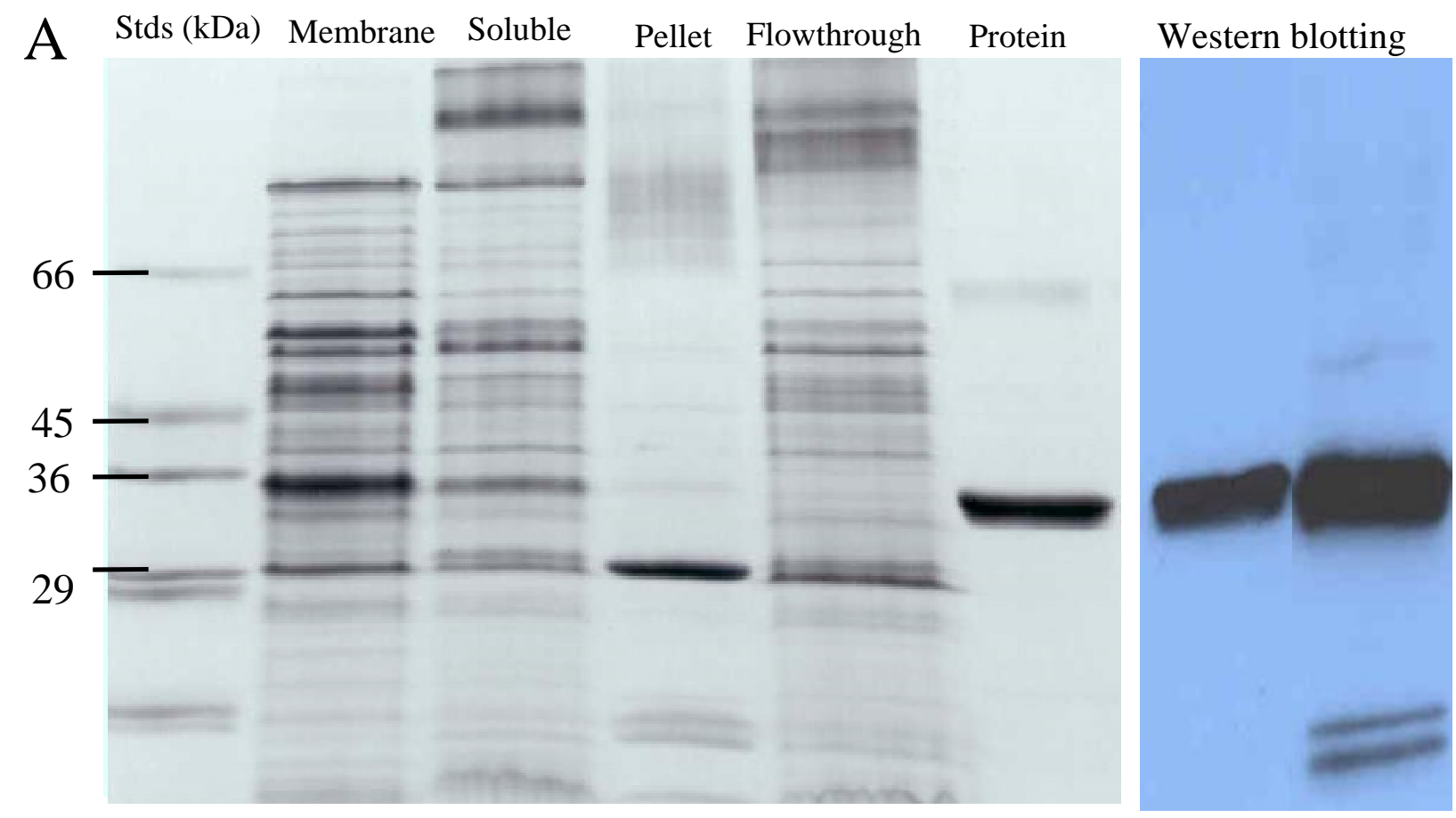

\section{Figure 3A}

C2005 Biochemical Society 
Published in Biochemical Society Transactions Volume 33, part 4

http://www.biochemsoctrans.org

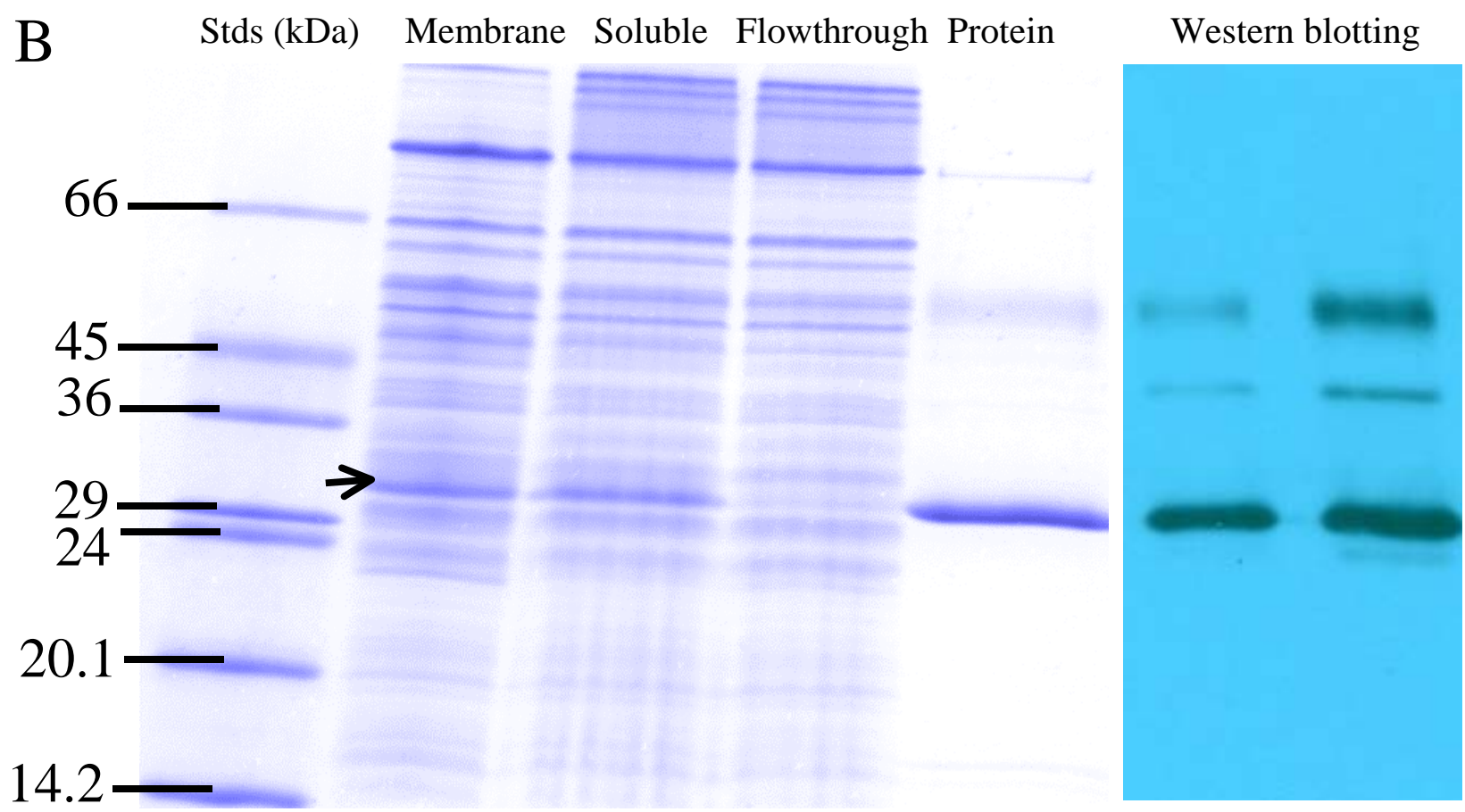

